\title{
Zasady edycji okolicznościowej literatury politycznej XVIII wieku
}

Janusz Maciejewski 


\section{Janusz Maciejewski}

\section{Zasady edycji okolicznościowej literatury politycznej XVIII wieku}

$\mathrm{O}$ mawiane $\mathrm{w}$ tym szkicu praktyki i wyrastające $\mathrm{z}$ nich zasady edytorskic ukształtowały się w trakcie prac nad przygotowaniem krytycznego wydania okolicznościowej literatury politycznej czasów konfederacji barskiej, a więc bardzo konkretnego zjawiska mieszczącego się w niespełna pięcioleciu. Było ono jednak cząstką większego obszaru — ważnego elementu sarmackiej formacji kulturowej w jej schyłkowym okresie, kiedy sąsiadowała już z rozwijającym się Oświeceniem ${ }^{1}$. Można więc zasadnie przyjąć, że ustalenia zrodzone $z$ refleksji towarzyszącej pracom nad tekstami lat 1767-1772 mogą być przydatne dla wydawcy podobnego typu literatury poprzedzających kilkudziesięciu, a także następnych kilku czy nawet kilkunastu lat. (A więc w zasadzie większości XVIII stulecia).

Twórczość okolicznościowo-polityczna trzeciej ćwierci XVIII wieku, tak pod względem językowym, jak i kulturowym, tkwi jeszcze w klimacie staropolskim, stanowi przedłużenie sarmatyzmu — choć pojawiają się w niej także symptomy zwycięskiej już w nurcie oficjalnym oświeceniowej formacji. W pełni jednak nowy typ polszczyzny, a także wyrażanego przez nią stosunku do świata, wystąpi dopiero w twórczości Sejmu Wielkiego.

Literatura okresu konfederacji barskiej mieści się więc przed cezurą dzielącą epokę staropolską od nowoczesnej. Dlatego też dla jej edytora mogą być instruktywne i stanowić punkt wyjścia Zasady wydawania tekstów staropolskich przygotowane przez zespół pod kierun-

\footnotetext{
1 O miejscu w kulturze omawianego tu od strony edytorskiej zjawiska pisałem w szkicu: Folklor środowiskowy. Sposób jego istnienia, cechy wyodrębniajace. (Na przyktadzie ", folklonu" szlacheckiego XVII i XVIII wieku), [w:] Problemy socjologii literatury, red. J. Sławiński, Wroclaw 1971 oraz w książce Dylematy wolności. Zmierzch sarmatyzmu i początki Ośuiecenia w Polsce, Warszawa 1994, s. 27 - 107.
} 
kicm Marii Renaty Mayenowej i opublikowane w 1955 r. $^{2}$ (W praktyce zresztą wykorzystywane i przy edycjach tekstów późniejszych). Oczywiście, tylko punkt wyjścia, gdyż nie wszystko, co tam ustalono, da się literalnie zastosować do literatury barskiej ze względu na jej specyfikę (o której za chwilę). I nie tylko z tego powodu: w wielu miejscach same Zasady... nie dają jednoznacznej odpowiedzi, zostawiając pole do indywidualnych rozstrzygnięć. Niemniej wiele rozwiązań sprawdzonych już wieloletnią praktyką — zwłaszcza dotyczących zakresu i rodzaju zabiegów modernizacyjnych - możemy przejąć z Zasad... i uznać za własne przy edycji literatury barskiej.

Edycja ta mieści się w grupie, którą autorzy Zasad... określają jako „typ B”. Ogranicza się on do transkrypcji utworów. Nie przewiduje ani fototypii, ani transliteracji tekstu (ta pierwsza - oczywiście w niewielkim wyborze - może wystąpić tylko jako materiał ilustracyjny). Podstawę tekstową — szczegół wyróżniający właśnie literaturę barską -- stanowią przy tym (z kilku wyjątkami z ostatnich miesięcy konfederacji) wyłącznie rękopisy. Druki pochodzą dopiero z XIX wieku. Są to wydania niekrytyczne i choć w niektórych przypadkach mogą służyć jako materiał pomocniczy, nie kwalifikują się w żadnym razie, aby je przyjąć jako podstawę edycji.

Dokonując transkrypcji utworów barskich z rękopisów, kierujemy się oczywiście wskazaniami zawartymi w Zasadach... Ale napotykamy podczas opracowywania tekstów także problemy nie przewidziane przez nie. Owe Zasady... zostały bowiem ukształtowane przez praktykę tego nurtu filologii, który można by nazwać filologią autorską. Wpisane jest weń założenie, że każdy tekst ma swego indywidualnego, osobowego sprawcę. Nawet jeśli ten ostatni nie jest znany, zakłada się, że był, toteż uprawnione wydaje się dążenie do odkrycia wśród różnych wersji danego utworu „tekstu autorskiego”, a za taką uznaje się „ostateczną postać nadaną tekstowi przez pisarza” " Jeśli nie posiadamy autografu, znamy natomiast kilka różniących się wersji danego utworu, według kanonu tejże filologii, powinniśmy zmierzać do wyodrębnienia „tekstu prymarnego” jako najbliższego zakładanemu tekstowi autorskiemu. W ogóle starania filologa prowadziłyby do stworzenia „tekstu kanonicznego”, ostatecznej, uwolnionej od wszelkich błędów i uszkodzeń wersji utworu, która winna stać się jedynie obowiązującą postacią tekstową dzieła.

Tego typu postępowanie jest niemożliwe dla edytora okolicznościowej literatury politycznej - nie tylko zresztą interesującego nas okresu. Przede wszystkim w niewiclu przypadkach są znani autorzy utworów. W większości są one anonimowe i to anonimowością nie przypadkową, ale wpisaną w status tekstu, jego sposób istnienia. Wiąże się to z faktem, iż w ciągu

\footnotetext{
2 K. Górski, W. Kuraszkiewicz, F. Pepłowski, S. Saski, W. Taszycki, S. Urbańczyk, S. Wierczyński, I, Woronczak, Zasady wydawania tekstów staropolskich. Projekt, pod red. M. R. Mayenowej, przy udziale Z. Florczak, Wrocław 1955.

${ }^{3}$ Ibidem, s. 63.
} 
pierwszej połowy XVIII wieku okolicznościowa literatura polityczna niemal w całości znalazła się w obrębie „folkloru szlacheckiego”. Był to wszak typ kultury niepersonalistyczny, $\mathrm{z}$ autorem - podobnie, jak w folklorze chłopskim - w zasadzie zbiorowym. Podmiotem w utworach literackich było „my”, nie zaś ,ja” autorskie. Gospodarzem tekstu, uprawnionym do jego tworzenia, korygowania, uzupełniania czuł się każdy członek zbiorowości, którą dany utwór wyrażał. Ową zbiorowością mogła być jakaś „fakcja” polityczna, grupa regionalna, sąsiedzka, czasem „my” - szlachta polska w całości.

Przygotowując zatem wydanie okolicznościowej literatury politycznej, w większości przypadków nie mamy możliwości ustalenia tekstu autorskiego. Co więcej: choć może to wyglądać na paradoks, właśnie przy tejże edycji, z przyczyn wyżej zasygnalizowanych, nie jest to najbardziej istotne. Skoro bowiem za tekstem stoi nie jednostkowy jego twórca, lecz taka czy inna zbiorowość, wówczas każdy członek owej zbiorowości może czuć się upoważniony do współautorstwa tekstu. Tak więc i ten, kto gospodarował w nim później, może sobie rościć takie samo prawo do zmieniania jego kształtu, jak ten, kto był pierwszy. Dzieje się tak niezależnie od tego, czy utwór jest całkowicie anonimowy, czy zachowało się nazwisko autora. Także w drugim przypadku zbiorowość, która uznała go za własny, może się czuć uprawniona do jego korygowania i - w jej przekonaniu — doskonalenia. Klasyczny tego przykład mamy w dziejach naszego hymnu narodowego. Znamy autora jego pierwotnej wersji. Napisał on w pierwszej zwrotce utworu: „Jeszcze Polska nie umarła, kiedy my żyjemy, co nam obca moc wydarła, szablą odbijemy". Legioniści, w których imieniu Wybicki tworzył tę pieśń, śpiewając ją, zmienili wersy pierwszy oraz trzeci na: „Jeszcze Polska nie zginęła” i „Co nam obca przemoc wzięła”. Właśnie w tym kształcie słownym utrwaliła się ona w pamięci narodu. Czy mamy uznać go za skażony, godny odrzucenia? Chyba nie, choć nie jest on tekstem autorskim. Wypada go uznać za równoprawny wariant utworu. Tym bardziej winniśmy tak czynić, gdy w ogóle nie znamy autora żadnej z wersji dzieła i w dodatku nie jesteśmy w stanie ustalić, która z nich jest wcześniejsza, a która późniejsza.

I tu dochodzimy do problemu drugiego z terminów klasycznej filologii: „tekst prymarny”. Jak powiedziałem, najczęściej trudno go ustalić. Większość dostępnych nam przekazów poszczególnych utworów okolicznościowej literatury politycznej powstawała równocześnie lub prawie równocześnie. Ale nawet tam, gdzie udałoby się odkryć jakąś ich czasową kolejność, trzeba uchylić zasadność wprowadzania tego terminu jako wartościującego, skoro uznaliśmy wyżej, iż każdy z „gospodarzy” tekstu ma w zasadzie takie samo do niego prawo. $\mathrm{Z}$ identycznych powodów musimy uchylić przydatność w naszych praktykach terminu „tekst kanoniczny”. (A jeśli czasem on zaistnieje - jak np. przybrał w pewnym momencie kształt kanoniczny tekst przywołanego wyżej Mazurka Dąbrowskiego - nie zawsze staje się nim tekst autorski i prymarny. $N b$. w przypadku literatury barskiej nie mieliśmy do czynienia $\mathrm{z}$ tego typu koniecznością).

Nie podejmując wielu wątków z klasycznej, ,autorskiej” filologii, możemy się natomiast powołać przy formułowaniu zasad edycji interesującego nas pismiennictwa na niektóre 
praktyki innego typu tekstologii - tej, która obowiązuje badaczy literatury ludowej. Jak wiadomo, w folklorystyce wszystkie warianty tekstu są równoprawne. Nie tworzy się hierarchii ani czasowych, ani przestrzennych, ani geograficznych. Tekst zapisany czy nagrany w Łęczyckiem lub Sieradzkiem, dziesięć lat wcześniej bądź później, traktuje się jako tak samo autentyczny. Badacz literatury folklorów środowiskowych może przejąc tę zasadę jako wyjściową, choć musi wnieść do nicj modyfikacje, wynikające choćby z tego, że ma do czynienia jednak z tekstem pisanym, nie zaś mówionym. Przekaz pisemny tym się różni od tego, który jest zakodowany jedynie w pamięci ludzkiej, iż możc być skażony, micć braki wynikające z niedoskonałości odpisu. Mogą więc zaistnieć odmiany między różnymi przekazami tego samego utworu, będące rezultatem błędu w jednym $z$ nich - i wówczas nie wolno nam traktować ich jako równoprawnych.

Nie dążąc zatem do ustalenia wersji prymarnej i autorskiej tekstu, musimy starać się o uzyskanie jego wersji poprawnej.

W przypadku literatury okolicznościowej czasów barskich wymaga to nawet sporych zabiegów. Rękopisy utworów, z jakimi mamy do czynienia, bynajmniej nie były pieczołowicie przygotowane. Rzadko odpisywali je dla siebie osobiście ci, którzy chcieli sami z nich korzystać. Częściej robili to sekretarze politykujących magnatów pragnących orientować się w nastrojach społecznych. Najczęściej zaś wychodziły one spod pióra zawodowych skrybów, piszących zbiorowo, pod dyktando, w kantorach — „gazeciarzy” rozsyłających później swym prenumeratorom teksty utworów jako załączniki do informacyjnych gazetek pisanych ${ }^{4}$. Przy tego typu technice powielania, gdy łatwo było się przesłyszeć, a nie stało czasu na zastanowienie, błędy pojawiały się nagminnie. Zdarzało się, iz przedstawiciel pierwszej z kategorii przepisywaczy dokonywał kopii z takiego właśnie skażonego egzemplarza. Dostrzegł błędy (często bowiem zakłócały one sens utworu), starał się je poprawić na własną rękę. Nie zawsze jego ingerencje prowadziły do przywrócenia właściwego kształtu danego fragmentu. Bywało, iż pozornie poprawiając tekst, dalej go zniekształcał.

Otóż do zadań edytora okolicznościowej literatury politycznej czasów konfederacji barskiej należy oczyszczenie tekstu z możliwie wszystkich błędów. A za takie — przypominam - uznajemy zmiany wynikające nie ze świadomego „gospodarowania” w tekście kolejnych przedstawicieli zbiorowości poczuwającej się do własności tego tekstu (a więc swoistych współautorów), lecz z pośpiechu, nieuwagi, złego odczytania pierwowzoru, przesłyszenia się piszącego pod dyktando skryby — i wreszcie — z niefortunnych prób usunięcia błędu. Nie zawsze powrót do pełnej poprawności jest możliwy, powinniśmy jednak do tego ideału dążyć.

Jak praktycznie należy postępować? Jeśli mamy do dyspozycji tylko jeden zachowany przekaz utworu, pozostaje nam — gdy skażenie jest ewidentne — wprowadzić niezbędne

\footnotetext{
${ }^{4}$ Informację tę zawdzięczam Jerzemu Jacklowi przygotowującemu edycję wyboru XVIII-wiecznych gazetek pisanych.
} 
koniektury. Jest to sytuacja niewątpliwie trudna. Na szczęście bywa ona w interesującym nas okresie stosunkowo rzadka. Większość utworów barskich dotrwała do naszych czasów $\mathrm{w}$ wielu, niekiedy bardzo licznych, przekazach. Wówczas metoda porównawcza wersji różnych rękopisów może być bardzo owocna w staraniach o przywrócenie poprawnego oblicza tekstu i usunięcia wszystkich błędów.

Pozostaje sprawa odmian wynikających nie z błędu, lecz wariantności tekstu. Tego typu różnice - jak zostało powiedziane wyżej — respektujemy w edycji. Samo takie stwierdzenie nie rozwiązuje jednak problemu, gdyż przyjęliśmy jednocześnie typ B edycji, zakładający pewną skrótowość aparatu badawczego, rezygnujący z pełnego oddania procesu filologicznego związanego $z$ tekstem. Publikujemy zatem w całości jedną wersję utworu. Odmiany występujące w innych jego przekazach odnotowujemy tylko w przypisach ( $n b$. jedynie istotniejsze odmiany — co dokładniej należy pod tym rozumieć, będzie wyjaśnione niżej). Tylko przy bardzo daleko idących różnicach decydujemy się publikować równocześnie dwie, a nawet trzy wersje danego utworu. (W naszej edycji będą to zresztą przypadki bardzo rzadkie).

Postępowanie edytora będzie się zatem zaczynać od wyboru rękopisu (w przypadku, gdy przekazów jest wiele), który ma służyć za podstawę edycji. Nie istnieją tu żadne żelazne reguły. Czasem o wyborze może zdecydować fakt, że ten właśnie przekaz jest najłatwiej dostępny czy po prostu najbardziej czytelny. Niemniej możemy sformułować pewną dyrektywę praktyczną postępowania, która brzmi: winniśmy starać się o dobór przekazu o stosunkowo najmniejszej ilości braków czy odmian, które trzeba uznać za błąd przepisywacza. Dodatkowym zaleceniem jest wybór tekstu najpełniejszego, najbogatszego (a więc takiego, przy którym nie będzie trzeba odnotowywać nieobecnych w przekazie podstawowym fragmentów tekstu). Oczywiście, istnieje niebezpieczeństwo sprzeczności między obu dyrektywami: może się zdarzyć, iż przekaz stosunkowo najbardziej poprawny, posiadający najmniej błędów, ma jakąs istotną lukę w tekście. Wówczas trzeba wybierać. Bywa jednak, iż lepiej jest dać tekst mniej pełny, ale poza tym zawierający najmniejszą ilość błędów, natomiast brakujący w nim fragment - występujący w innym rękopisie czy rękopisach — zamieścić albo w przypisic (jeśli różnicę uznamy za wynikającą z wariantności porównywanych przekazów), albo w tekście głównym (jeśli dojdziemy do przekonania, iż stanowi on jego integralną część, omyłkowo tylko pominiętą przez przepisywacza). Naturalnie, w jednym i drugim przypadku decyzję naszą musimy w przypisie ujawnić i uzasadnić.

Odrębną sprawę stanowią utwory (wprawdzie nieliczne), które były dopełniane, których tekst z czasem przyrastał. Mamy oczywiście obowiązek uwzględnić w edycji wszystkie jego części, niezależnie od tego, czy uznamy za podstawową wersję najobszerniejszą, czy też z takich lub innych powodów oprzemy poszczególne jego części na różnych przekazach. Musimy tylko ujawnić w komentarzu filologicznym (w jednym i drugim przypadku), w którym miejscu kończy się jedna i zaczyna kolejna część utworu, ewentualnie także zasygnali- 
zować to graficznie w tekście głównym. (W takim przypadku należy także uprzedzić o fakcie we wstępie-metryczce do utworu).

Jak więc powiedziałem, wybieramy jako podstawę edycji jeden przekaz. Respektujemy jego kształt słowny, usuwając jednak błędy, głównie na podstawie materiału porównawczego innych przekazów. Każdą ingerencję odnotowujemy i uzasadniamy w przypisach. Tamże zamieszczamy takze istctniejsze, uznane przez nas za równoprawne warianty, odmiany tekstu występujące w innych przckazach.

Należy zatem teraz sprecyzować, co rozumiemy pod słowem ,istotniejsze”. Nie będą więc nimi nagminnie występujące zmiany szyku słów w zdaniach, a także sytuacje, gdy jakiś wyraz jest zastępowany w innych przekazach jego synonimem. Nie odnotowujemy braku jakichś cząstek w zdaniu, a nawet całych zdań, jeśli ich brak czy naddanie nie zmienia sensu kontekstu. Inaczej jednak postępujemy, gdy ów sens wchodzi w grę. I tu przyjmujemy zasadę, iż jeżeli rękopis podstawowy przynosi wersję szerszą, nie odnotowujemy faktu nieobecności danego zdania w innym manuskrypcie czy ich grupie - chyba, że jest to konsekwentne we wszystkich innych przekazach. W ostatnim przypadku oraz wtedy, kiedy owego modyfikującego sens zdania brakuje w rękopisie podstawowym, a występuje w innych, odnotowujemy ów fakt w przypisie.

W zapleczu dotąd ustalonego postępowania tkwi założenie, iż przekazów jest niewiele, kilka najwyżej. Tak zresztą bywa istotnie przy wiçkszości utworów barskich. Mamy jednak parę przypadków, gdy jest ich bardzo dużo. Dotyczy to m.in. dwóch dramatów: Perekińczyka i Cnoty uciemiężonej, wolności obarczonej. Wówczas po prostu fizycznie jest niemożliwe, aby porównać i odnotować warianty ich wszystkich. Dlatego w takich wypadkach przyjmujemy, iż edytor wybiera - poza rękopisem będącym podstawą wydania - kilka lub kilkanaście innych przekazów - tyle, ile potrzebuje, aby drogą porównawczą usunąć błędy tegoż rękopisu i tylko w ich zakresie odnotowuje także odmiany wariantne. Sygnatury innych podaje natomiast w metryce utworu.

Osobnym problemem przy przygotowywaniu edycji anonimowej, okolicznościowej literatury politycznej jest pytanie, jak potraktować wszelkiego typu poprawki w tekście, kreślenia, nadpisy itp. W „autorskiej” filologii sprawa jest prosta. Jeśli stwierdzimy, że są one prowadzone ręką autora, respektujemy je. Jeśli natomiast obcą ręką, uznajemy za próbę nieprawnego gospodarowania w cudzej własności i odrzucamy. U nas takie rozwiązanic jest niemożliwe. Możemy jednak posłużyć się pewną analogią: jeśli poprawki są tej samej ręki i nie zakłócają sensu, a zwłaszcza — w wierszu — rytmu całości, winniśmy je uznać i-jeżeli sprawa jest prosta - nawet nie odnotowywać tego w przypisie. Jeśli jednak decyzja jest trudna, konieczność poprawki budzi wątpliwości, warto ślad wahań zostawić w komentarzu. Podobnie trzeba postapić, kiedy poprawkę odrzucamy jako zakłócającą całość utworu.

Z bardziej skomplikowaną kwestią mamy do czynienia, gdy poprawki są innej ręki niż sam tekst. Wówczas raczej nie należy ich respektować, zwłaszcza, gdy znajdziemy świadectwo, iż są dużo późniejsze, np. z XIX wieku. Stulecie to było dość purytańskie. Często 
właściciele rękopisów w tym okresie cenzurowali to, co odziedziczyli po dziadach, np. wykreślając bądź zamazując wyrażenia odbierane przez nich jako nieprzyzwoite. Mamy nie tylko prawo, ale obowiązek tego typu ingerencje usuwać). Użyłem wyżej słowa „raczej”, gdyż bywają jednak wyjątki. Może dopisek innej ręki (nawet owego przywołancgo wyżej wnuka) ingerować w miejsce, gdzie był ewidentny błąd (który my sami też powinniśmy poprawić). Wówczas możemy tę właśnie poprawkę respektować, odnotowując całą rzecz w przypisie.

I ostatnia sprawa tego typu: sposób zaznaczania miejsc uszkodzonych bądź nieczytelnych. Stosujemy wówczas nawiasy kwadratowe, wewnątrz których umieszczamy kropki albo skrót „nieczyt.”. W takież nawiasy ujmujemy słowo, które jest naszą hipotetyczną rekonstrukcją nieczytelnego bądź uszkodzonego miejsca. Możemy również w klamry ująć wyrazy bądź litery pominięte naszym zdaniem pomyłkowo, jeśli nie jesteśmy pewni, że tak właśnie ono brzmiało (przy najmniejszych jednak wątpliwościach, także kwitując rzecz w przypisie).

Dotąd omawiane problemy filologiczne bardzo duży zakres działań pozostawiały indywidualnej decyzji edytora. Teraz trzeba przejść do bardziej sztywnych (a więc i wygodniejszych) reguł, w większości skodyfikowanych w przywołanych na początku tych rozważań Zasadach. Do najważniejszych należy postulat modernizacji pisowni według dzisiaj obowiązujących zasad ortograficznych. Ale - co bardziej ważne — modernizując pisownię, staramy się nie zniekształcać różnych cech ówczesnej wymowy. Respektujemy różnego typu dialektyzmy, zachowujemy formy spieszemy, radziemy, wytamowali (zamiast spieszymy, radzimy, wytamywali), oboczność sluby / szluby itp. Jednak i tu mamy pewne wyjątki. Sprowadzamy do dziś obowiązujących form nagminnie występujące w wydawanych utworach $O$ w miejscu $A$ oraz odwrotnic $A$ zamiast $O$ lub ON (np. kączy zamiast kończy). Są one niewątpliwie symptomem chwiejności ówczesnej wymowy, ale abyśmy mogli ją oddać, trzeba by wprowadzić specjalny znak. Podobna sytuacja jest z formami lepi, gorzy, które zmieniamy na lepiej, gorzej. Także konsekwentnie, nie zważając na wymowę, normalizujemy według współczesnych zasad ortograficznych dźwięczność i bezdźwięczność spółgłosek. Poprawiamy zatem schacka na schadzka, kłótki na kłódki choć tak wówczas, jak i dzisiaj, wymawiamy to słowo bezdźwięcznie.

Natomiast osobnym problemem jest sprawa transkrypcji zbitki literowej $Y A$ w takich wyrazach, jak Marya, tragedya, konfederacya. Zgodnie z przeważającymi praktykami modernizacyjnymi winniśmy je oddawać jako Maria, tragedia, konfederacja (wyjątki na rzecz dwuzgłoskowości czyni się tylko dla potrzeb rytmicznych wiersza). Ale wówczas kłóciłoby się to z osicmnastowieczna wymową, właśnie dwusylabową - co poświadczają językoznawcy zajmujący się historią polszczyzny. Wobec tego zdecydowaliśmy YA oddawać jako $Y J A$ (Maryja, tragedyja, konfederacyja) bądź IJA (Danija).

Jeśli nie zachodzą powyższe przypadki, postępujemy dość mechanicznie. Przykładowo: dawne I oraz $Y$ oddajemy — odpowiednio — przez jotę $[J]$, krótkie $I$ oraz $Y$. Także rezygnu- 
jemy z podwójnych spółgłosek w wyrazach obcego pochodzenia, np. kollacja, klassa poprawiamy na kolacja, klasa. Wielkie i małe litery stosujemy według obecnie obowiązujących przepisów (jednak w zapisie zwrotów grzecznościowych — przy i dziś istniejącej chwiejności w tym zakresie - zachowujemy wielkie litery, np. Waszmość Panus). To samo dotyczy pisania łącznego i rozdzielnego oraz statusu cząstek typu bych, byś, by oraz przedrostków. Konsekwentnie wreszcie modernizujemy interpunkcję. (Wprawdzie Zasady... zachowują wyjątek dla świadomych, niejako autorskich propozycji interpunkcyjnych, ale taki casus nie zachodzi w tekstach okolicznościowej literatury politycznej).

Rozwiązujemy również skróty: W. M. P. na Waszmośc Pan, J. K. M. na Jego Królewska Mość, $w$-dztwa na województwa itp. Zachowujemy jednak skróty utarte, w tej formie wymawiane. Tak np. Waszmość nie zamieniamy na Wasza Mitość czy Mospanie bądź Mości Panie nie sprowadzamy do formy Mitościury Panie.

Wyżej zasygnalizowane (przykładowo) modyfikacje są z grubsza w zgodzie z duchem Zasad wydawania tekstów staropolskich (choć nie wszystkie były przez nie przewidziane). W jednym jednak wypadku przyjmujemy odmienne niż one rozstrzygnięcie. Zasady... podają:

Normalizujemy końcówki narzędnika i miejscownika l. poj. rodz. męskiego i nijakiego oraz celownika i narzędnika 1. mn. YM, EM, YMI, EMI według pisowni dzisiejszej, zostawiając formy niezgodne z obecnymi przepisami tylko tam, gdzie tego wymaga czystość rytmu ${ }^{5}$.

Otóż wydaje się, iż ta zasada, niewątpliwie słuszna przy tekstach XIX i XX wieku, w epokach wcześniejszych (a w każdym razie naszej) zbyt koliduje z nadrzędną zasadą respektowania właściwości wymowy. Dlatego w tej edycji są zachowane końcówki EM, EMI, a $z$ drugiej strony pisownia potym nie jest modernizowana na potem.

${ }^{5}$ Zasady wydawania tekstów staropolskich, op. cit., s. 98. 